Adult male Swiss-webster mice were implanted with permanently indwelling cannulae with tips within the lateral cerebral ventricle. The neuropeptide dynorphin was infused centrally and subjects were tested on a variety of behavioral tasks. Peptide treated mice were more likely than vehicle treated mice to eat and groom. At higher doses, dynorphin treated mice showed barrel rotation which was occasionally succeeded by death. Effects upon behavior were only partially reversible by naloxone.

\title{
Introduction
}

Dynorphin is a recently isolated and partially identified neurohypophyseal peptide (Goldstein, Tachibana, Lowney, Hunkapiller and Hood, 1979). It is of particular interest because it may be the normal biological precursor for Leu-enkephalin, and may itself possess biological activity. At present its actions in vivo are not well established, although preliminary reports indicate potential roies in catalepsy and analgesia (op. cit.).

We report herein a number of effects suggesting the compound may be broadly involved in the regulation of motivation and behavior. Our results also suggest at least some of these effects are unrelated to classic opiate receptor stimulation.

\section{Materals and Methods}

Adult male Swiss-webster mice $(30 \pm \bar{g}$ ) were surgically prepared with permanently indwelling cannulae as described in detail in previous reports (Katz, Carroll and Baldrighi, 1978). briefly, a single 23 ga. stainless steel needle was stereotaxically implanted within the lateral ventricle based on co-orainates $(-2.2,-1,-2.2 \mathrm{~mm})$ from Slotnick and Leonard (1975). The cannula was anchored to the skull with three 0-60 stainless steel screws and acrylic dental cement. One week of recovery was allowed before testing with vehicle or drug. Dynorphin (Peninsula Laboratories, San Carlos, Calif.) was prepared fresh in polypropylene containers and injected intracerebroventricularly 0,25 , and $50 \mu g$, in $5 \mu l$ of $0.9 \%$ sodium chloride vehicle. we have found this injection volume to produce few effects upon behavior (Katz et al., 1970). Time between preparation of the solution and injection was 20 sec or less, and injections were completed with an infusion time of less than $20 \mathrm{sec}$. Mice were observed in $51 \times 41 \times 22 \mathrm{~cm}$ polypropylene cages (Scientific Products, Series 70$)$ to which they had been extensively $(96 \mathrm{~h})$ habituated in 12 previous sessions. Four hours placement in the cages immediately preceded injections and observations.

A bedding of fresh pine chips was placed on the cage floor and five food pellets (Teklad $4.0 \%$ fat diet S-0836) were scattered randomly throughout the cage. Behaviors were observed tive, ten, fifteen, and twenty minutes after injection for one minute periods, and rated on a presence/absence scale. The following categories of behavior were rated: forward locomotion, grooming and eating. Scores of ratings were summed within categories to produce a behavioral score ranging from 0 to 4 . For example, a mouse observed to be feeding in each of the observation periods would have a net feeding score of 4.0 . 


\section{Results}

Vehicle injections produced no remarkable changes in behavior although some forward locomotion was present for the initial 10 minutes. Peptide injected mice at the lower dose showed consistent feeding and grooming. The higher dose produced violent barrel rotation in half the mice tested, and this was followed by substantial $(50 \%)$ mortality within 60 minutes of injection. Results are present 6 d in Table cne. Naloxone reversibility is considered a criterion of pharmacological specilicity for opiate effects, and a separate group of mice was pretreated with naloxone $\mathrm{HCl} 14.0 \mathrm{mg} / \mathrm{kg}$ intrilueritoneally ten minutes prior to central injection; control mice received $0.9 \%$ sodium chloride vehicle pretreatment). It may further be seen in Table one that blockade by naloxone had only slight effect upon the behavioral effects of dynorphin. It should be noted that naloxone was tested against $25 \mu 8$ of peptide except for the case of barrel rotation. A higher dose of peptide was required to elicit the rotational syndrome itself. Upon statistical analysis, the reductions proved no different than dynorphin effects. It should be noted this is a behaviorally active dose of naloxone against opiates of various classes in other tests (Katz et al., 1978; Stein and Belluzzi, 1970). From this analysis it is evident that dynorphin possesses behavioral activity in vivo and that this may at least partly be dissociated from the occupation of oplate receptors. Histological examination ten minutes following injection of $5 \mu l$ black ink into the ventricles indicated complete diffusion along the ventricular system.

TABLE ONE

Effects of the Upioid Peptide Dynorphin upon Behavior in the Mouse (Mean score + SEM)

\begin{tabular}{|c|c|c|c|c|c|}
\hline $\begin{array}{l}\text { Dose }(\mu g) \\
\text { Category }\end{array}$ & 0 (Venicle) & $\begin{array}{l}\text { Naloxone + } \\
\text { Vehicle } \\
(n=6)\end{array}$ & $\begin{array}{c}25 \\
(n=6)\end{array}$ & $(n=6)$ & $\begin{array}{c}25+\text { Naloxone } \\
(4 \mathrm{mg} / \mathrm{kg}) \\
(\mathrm{n}=6)\end{array}$ \\
\hline Locomotion & $.6 \pm .3$ & $\cdot 3 \pm \cdot 3$ & $1.5 \pm .5^{a}$ & $1.3 \pm .3^{a}$ & $1.2 \pm .2$ \\
\hline Grooming & $.1 \pm .2$ & $0 \pm 0$ & $2.0 \pm .7^{\mathrm{a}}$ & $1.6 \pm .3^{a}$ & $2.0 \pm .7$ \\
\hline Eating & $.11 \pm .10$ & $.5 \pm .5$ & $1.3 \pm \cdot 3^{a}$ & $1.0 \pm .5^{a}$ & $.8 \pm .5$ \\
\hline $\begin{array}{l}\text { Barrel } \\
\quad \text { Rotation }\end{array}$ & 0 & 0 & 0 & $1.3 \pm .4^{\mathrm{c}}$ & $1.1 \pm .2$ \\
\hline
\end{tabular}

a $p<05$ vs control based upon 2-sample independent $\underline{t}$-test

b $p<05$ vs $25 \mu \mathrm{g}$ score based upon 2-sample independent t-test

c differs from control p<05 by randomization test

d naloxone effect evaluated is $50 \mu \mathrm{g}$ not $25 \mu \mathrm{g}$ for barrel rotation only

\section{Discussion}

The findings are of interest in identifying some possible roles for dynorphin in behavioral regulation. The fact that the arug elicits feeding and grooming is consistent with a view of endorphins as "satisfiers" as proposed by stein and colleagues (1978). The present results indicate only partial naloxone reversibility for grooming and feeding. It must be considered that partial reversibility may indicate certain behavioral functions extrinsic to opiate receptors, and this indeed would extend stein's notion to non-opioid receptors. 


\section{Keferences}

Goldstein, A., Tachibana, S., Lowney, L.l., Hunkapiller, h. and hood, L. (1979). Dynorphin (1-13) An extraorinarily potent opioid peptide. Proceedings of the National Academy of Sciences 76: 6666-6670.

Katz, R.J., Carrol1, B.J. and Ealdrighi, G. (1978). Behavioral activation by enkephalins in mice. Pharmacology. Elochemistry and Eehavior 8: 493-496.

Slotnick, E.M. and Leonard, C.M. (1978). A stereotaxic atlas of the albino mouse forebrain. U.S. Department of Health. Education, and Welfare Publication ADN 25-100, washington, D.C., pp. 171.

Stein, L. and belluzzi, J.D. (1978). Brain endorphins and the sense of well being--A psychobiological hypothesis. In: The Endorphins, Advances in biochemical Psychooharmacology, (Costa E. and Trabucchi, M., Eds.), Vol. 18, pp. 299-31a. Kaven, New York. 